\title{
Improvement of Kolbroek Boar Growth Performance and Carcass Quality through Dietary Crude Protein Supplementation
}

\author{
T. R. Netshirovha ${ }^{1,2}{ }^{*}$, D. O. Umesiobi ${ }^{3}$, M. B. Matabane', M. L. Mphaphathi' ${ }^{1}$, C. M. Pilane1, \\ S. R. Thomas ${ }^{1}$, P. Sebothoma ${ }^{1}$, A. T. Kanengoni ${ }^{4}$, T. L. Nedambale ${ }^{1,5}$
}

\footnotetext{
${ }^{1}$ Agricultural Research Council (ARC), Animal Production, Germplasm Conservation and Reproductive Biotechnologies, Private Bag X2, Irene, South Africa

${ }^{2}$ School of Agriculture and Environmental Sciences, Faculty of Health and Environmental Sciences, Central University of Technology, Private Bag X20539, Free State, Bloemfontein, South Africa

${ }^{3}$ Mammal Research Institute (MRI), University of Pretoria, Private Bag X20, Hatfield, South Africa

${ }^{4}$ Veterinary Services and Research Department, Joburg Zoo, Private Bag X 13, Parkview, Johannesburg, South Africa

${ }^{5}$ Department of Animal Science, Tshwane University of Technology, Private Bag X680, Pretoria, South Africa

Email: *netshirovhat@arc.agric.za
}

\begin{abstract}
How to cite this paper: Netshirovha, T.R., Umesiobi, D.O., Matabane, M.B., Mphaphathi, M.L., Pilane, C.M., Thomas, S.R., Sebothoma, P., Kanengoni, A.T. and Nedambale, T.L. (2020) Improvement of Kolbroek Boar Growth Performance and Carcass Quality through Dietary Crude Protein Supplementation. Open Journal of Animal Sciences, 10, 502-513.
\end{abstract}

https://doi.org/10.4236/ojas.2020.103031

Received: February 19, 2019

Accepted: June 21, 2020

Published: June 24, 2020

Copyright $\odot 2020$ by author(s) and Scientific Research Publishing Inc. This work is licensed under the Creative Commons Attribution International License (CC BY 4.0).

http://creativecommons.org/licenses/by/4.0/

(c) (i) Open Access

\begin{abstract}
Kolbroek pigs have numerous advantages as an indigenous breed including its contributions to food security. However, there are numerous concerns over the current feed regime that compromises its growth performance and carcass quality. Therefore, this study was conducted to evaluate the growth performance traits, attainment of puberty, backfat thickness (BFT), and carcass traits when boar fed diets supplemented with 10\% (standard diet), 13\% and $16 \%$ crude protein. Fifteen pigs per protein diets were individually housed and fed ad-libitum for eight weeks in a complete randomised design. Average daily gain (ADG), average daily feed intake (ADFI) and feed conversion ratio (FCR) were measured on a weekly basis. At the end of the trial, all boars were slaughtered and carcass quality parameters measured. Pearson's correlation coefficients were calculated between growth performance parameters. Our data revealed that there was an increase in final body weight, ADG, ADFI accompanied by decreases in BFT and the age of attainment of puberty. There was also a positive correlation between ADFI and ADG $(r=$ 0.78 ) accompanied by a low positive correlation between ADG and BFT ( $r=$ $0.12)$ with a high negative correlation between FCR and ADG $(r=-0.94)$. The water holding capacity (WHC), dressing percentage and marbling mass appeared to decrease while the eye muscle area increased with protein supplementation of the diet. There were also increases in the lungs, liver, small plus large intestines and stomach with no changes in the pancreas and heart
\end{abstract}


tissues. Accompanying these was observations that the meat colour lightness improved accompanied by a decline in meat redness and yellowness. In conclusion, supplementation of boar diet with increasing crude protein improved the carcass quality and growth performance of Kolbroek boars.

\section{Keywords}

Growth Performance, Carcass Traits, Protein Diet, Kolbroek Pigs

\section{Introduction}

Kolbroek pigs are popular among local pig breeders. It forms part of national assets, which are being conserved to maintain the breed genetically pure. It contributes to poverty alleviation, as a protein source. Kolbroek pigs are a South African indigenous pig breed that possesses valuable traits, such as longevity, disease tolerance and adaptability to harsh environmental conditions in addition to its contributions to food security [1]. They are small sized, weighing about 0.5 $\mathrm{kg}$ at birth and about $45.5 \mathrm{~kg}$ at one year of age [2]. They also have been recommended as good alternative sources of protein that can provide additional income especially for local rural farmers [3]. Current literature has shown that indigenous pigs tend to have thicker back-fat compared to exotic breeds, which prevents them from receiving good carcass grades [4]. However, there are observations that Kolbroek pigs are less efficient as protein sources because of their tendency to put on excess back fat [5]. These may be because the standardised protein requirement for Kolbroek boars has not been ascertained [3]. These pigs are typical fatty pig breeds with $28 \%$ to $35 \%$ of meat quality [6] [7]. Due to economic reasons and customer demands, pig producers use nutrition to improve their carcass quality with low fat content [6] [8]. Moreover, the body weight of a boar is an important indicator of its growth, health and readiness to go to market [9].

Low nutrient levels can easily be met through use of locally available feed resources, such as leguminous leaf meals, groundnut hulls, sunflower cakes and other fibrous protein sources [10]. These nutrients influence the growth performance and carcass quality in boars. Many farms feed boars on sow diets, but the feeding program may neglect some of the unique nutrient requirements that must be met to optimize breeding sire reproductive performance [11]. In addition, low protein diets have been shown to further delay attainment of puberty and reduce boar libido [12].

Back fat thickness (BFT) is one of the important economic traits that are used to assess the carcass quality [13]. It is generally presumed that back fat depth positively correlates with growth and reproductive traits in male animals [14]. It is thus conceivable that selection based primarily on productive characteristics, especially for lean growth, leads to reproductive problems, such as low spermatozoa production and delays in libido expressions after weaning in boars [15]. 
Diet supplementation with crude protein (CP) could promote lean growth accompanied by decreased BFT and age of attainment of puberty.

The current study was conducted to assess the effect of dietary protein supplementation on growth performance, puberty attainment, BFT, visceral organs and carcass traits of Kolbroek boars. We hypothesized that dietary protein levels have minimal effects on growth performance, puberty attainment, BFT, visceral organs and carcass traits of Kolbroek pigs.

\section{Materials and Methods}

\subsection{Animal Care}

The experiments were carried out at the Pig Research Unit of Germplasm Conservation and Reproductive Biotechnologies Programme at the Agricultural Research Council (ARC), Irene, South Africa. The ARC-AP campus is located at $25^{\circ} 55^{\prime}$ South; $28^{\circ} 12^{\prime}$ East. The campus is located in the Highveld region of South Africa and situated at an altitude of $1525 \mathrm{~m}$ above sea level. The experimental protocols were evaluated and approved by the Animal Ethics Committee of the Agricultural Research Council-Animal Production (APIEC13/002).

\subsection{Experimental Design, Animals and Diets}

A total of 45 Kolbroek boars were used in this study at the (average $\pm 1.5 \mathrm{~kg}$ ) and reared until 14 weeks (live weight $\pm 13.4 \mathrm{~kg}$ ). The boars were kept in pens that were equipped with self-feeders and automatic water nipples. Feeds were offered ad libitum at birth until weaning. After weaning, pigs were given punch creep feeding for 4 weeks. The experimental boars were randomly allocated to three protein diets, namely, diet $1(10 \% ; n=15)$; Diet $2(13 \% ; n=15)$ and Diet $3(16 \%$; $\mathrm{n}=15$ ) at week 18 of age until weeks 34 of age and (live weight $\pm 13.4 \mathrm{~kg}$ ) were used in this trial. Diets were formulated to meet the ARC pig nutritional requirements by using Format international-feed formulation software solutions (FI-FFSS) [16]. The proximate compositions of the experimental diets are presented (Table 1).

Table 1. Feed formulation and chemical compositions of ingredients on diets of growing Kolbroek pigs.

\begin{tabular}{cccc}
\hline & \multicolumn{3}{c}{ Levels of crude protein (\%) } \\
\hline Item & 10 & 13 & 16 \\
\hline $\begin{array}{c}\text { Ingredient }(\mathrm{kg} / \mathrm{g}) \\
\text { Wheat bran }\end{array}$ & 155.40 & 159.40 & 159.44 \\
Hominy chop & 300.00 & 355.24 & 350.50 \\
Maize meal & 495.70 & 399.00 & 304.10 \\
Soya oil cake & 120.60 & 121.00 & 121.50 \\
Monocalcium & 25.00 & 25.00 & 25.00 \\
Full Fat Soya Micro & 10.00 & 30.00 & 30.00 \\
Limestone & 6.00 & 16.00 & 13.00 \\
\hline
\end{tabular}




\section{Continued}

\begin{tabular}{cccc}
\hline Salt & 1.00 & 1.00 & 1.00 \\
Lysine hydrochloride & 0.60 & 0.70 & 0.80 \\
DL Methionine & 1.00 & 1.00 & 1.00 \\
Pig Supplement ${ }^{*}$ & 4.00 & 4.00 & 4.00 \\
Calculated composition (\%) & & & \\
Protein & 10.53 & 13.50 & 16.00 \\
Energy/MJ/KG DM & 17.70 & 17.00 & 18.00 \\
Fat & 4.50 & 4.70 & 5.50 \\
Phosphorus & 1.10 & 0.80 & 0.80 \\
Neutral Detergent fibre & 30.40 & 30.00 & 30.00 \\
Acid Detergent Fibre & 6.50 & 6.00 & 6.70 \\
Calcium & 0.90 & 0.90 & 0.90 \\
\hline
\end{tabular}

*The pig supplement contained vitamin A 6500000 IU; D3 1200000 IU; E 40000 IU; K3 2 g; B1 1.5 g; B2 4.5 g; B12 0.03 g; B6 2.5 g; Niacin 25 g; Calcium pantothenate 12 g; Choline 190.5 g; Folic acid 0.6 g; Biotin 0.05 mg; Manganese $40 \mathrm{~g}$; Zinc $100 \mathrm{~g}$; Copper $125 \mathrm{~g}$; Iodine 1g; Ferrous $100 \mathrm{~g}$ and Selenium $0.3 \mathrm{~g}$.

\subsection{Growth Performance, Attainment Puberty and Back Fat Thickness}

Average daily feed intake (ADFI) from each boar was calculated for each treatment every week, throughout the experimental period. Body weights (BW) were recorded on a weekly basis, prior to feeding, to estimate ADG. Feed conversion ratio (FCR) was calculated as the ratio of feed intake by the animals in each of the experimental pen divided by the total weight gain of the animals per pen. The amount of feed supplied to pigs was weighed and recorded. To calculate feed intake, the amount of feed inside the feed trough after every seven days was weighed and the weight of the leftover feed was then subtracted from the total feed supplied to the animals for the seven days. The ADFI was calculated by adding feed intakes for the entire experimental period and then dividing by the total feed intake, and the number of experimental units was divided by the total weight gain per pig. Backfat thickness of the live pigs was measured weekly by means of a Renco ultrasound P2 backfat probe supplied by Instavet SA. Kolbroek boars were fed ad libitum with liberal water supply, the feed intake and residual feed were weighed every day. Age at attainment of puberty was observed and evaluated at 5 months of age. The boars were monitored twice a week for attainment of puberty and the final weight was obtained at puberty.

\subsection{Carcass Traits and Meat Composition of Longissimus Muscle}

At the end of the experimental period, all boars were slaughtered and their average body weight determined. Pigs were processed according to the routine abattoir procedures, which included an ante mortem inspection and rest for the pigs before slaughter. The pigs were then stunned with an electrical stunner set at $220 \mathrm{~V}$ and $1.8 \mathrm{~A}$ with a current flow for $6 \mathrm{~s}$ and exsanguinated within $10 \mathrm{~s}$ of 
stunning. Warm carcass weights (WCW) were measured after dressing using an overhead scale. Visceral organs were removed immediately after removing the hairs, and automatic weighing scale was used to measure the weight. After the removal of the visceral organs, the remaining part was measured as carcass weight and later expressed as percentage of the live weight to get the dressing percentage. Dressing percentage calculations were determined as the cold carcass weight and expressed as a percentage of live weight. The carcass was placed in cold room for 24 hours after which the cold carcass weights (CCW) and lengths of carcass (CL) for each pig were determined. The carcass length was taken as a distance from anterior edge of the first rib to the pubic bone along median plane using a measuring tape [17]. Each carcass was then cut at the last rib up to the middle. All other carcass measurements were taken from the left side. A cut was made between the $10^{\text {th }}$ and $11^{\text {th }}$ ribs and carried on through the spinal column. The P2 fat measurement was taken on each carcass with Vernier callipers over the eye muscle, $60 \mathrm{~mm}$ from the carcass midline. Depth of the BFT was measured using a pair of Vernier callipers (Future Light (Gauteng, 0.05 $\mathrm{mm})$. Backfat thickness measurements were made between the $2^{\text {nd }}$ and $3^{\text {rd }}$ rib. Access was made to the loin for the measurements of the eye muscle length, eye muscle width and eye muscle-fat on the carcass. The lean meat percentage was calculated using the standardized formula $(\%$ lean $=72.5114-0.4618 \mathrm{~V}+$ 0.0547S). Drop loss was calculated as the warm carcass weight less the cold carcass weight. Water holding capacity (WHC) was measured according to the procedure of Hofmann and White, (1982) [18]. Briefly, a $0.3 \mathrm{~g}$ sample of muscle was placed in a filter-press device and compressed for $5 \mathrm{~min}$. After this process, WHC was calculated from duplicate samples as the ratio of the meat film area to the total area using an area-line meter (Super PLANIX-a, Tamaya Technics Inc., Tokyo, Japan). Meat colour was measured using a colorimeter (Colormeter CR-300, Minolta Co., Osaka, Japan) immediately after removing the meat from the polyethylene bag. The colour values of $L^{*}$ (lightness), $a^{*}$ (redness), and $b^{*}$ (yellowness) were repeatedly measured in the same manner. The standard white plate had a $y$ value $=93.60$, an $x$ value $=0.3134$, and a $y$ value $=0.3194$.

\subsection{Statistical Analysis}

Data were analysed using one-way analysis of variance (ANOVA). Shapiro-Wilk's test was performed to test for non-normality [19] [20]. Student's t-Least Significant Difference (LSD) was calculated at the 5\% level to compare treatment means of significant effects. Treatment means were separated using Shapiro protected t-test least significant difference (LSD). The data were presented as means \pm SEM.

\section{Results}

\section{Growth performance and age of puberty}

Our data revealed that there was an increase in final body weight with increase 
in supplemented protein diet with a body gain of $6.2 \mathrm{~kg}$ at $13 \%$ diet. In addition, there was an increase in total body weight gain as the protein supplementation was increased. Average daily gain was increased from $0.29 \mathrm{~kg} / \mathrm{day}$ to $0.33 \mathrm{~kg} / \mathrm{day}$ as the protein diet was increased. The BFT was decreased by $0.2 \mathrm{~cm}$ at $16 \%$ protein supplementation. Interestingly, the age of attainment of puberty was decreased by 3 days accompanied by loss of weight at puberty albeit insignificantly. The effects of dietary protein inclusion levels on growth performance of pigs are presented (Table 2).

This study revealed that the carcass length increased by $2 \mathrm{~cm}$ as the protein supplementation was increased. Warm and cold carcass weight also increased by $5.48 \mathrm{~kg}$ and $6.24 \mathrm{~kg}$ at $13 \%$ and $16 \%$ protein supplementation. Accompanying this was the lean meat percentage that increased by only $1 \%$ while the drip loss percentage increased by $0.1 \%$. Additionally, meat colour lightness improved accompanied by a decline in meat redness and yellowness (Table 4).

The effects of crude protein supplementation on visceral organ of the Kolbroek boars are shown (Table 5 ).

Table 2. Effects of dietary protein levels on growth performance of Kolbroek boars.

\begin{tabular}{cccccc}
\hline & \multicolumn{5}{c}{ Levels of crude protein (\%) } \\
\hline Item & 10 & 13 & 16 & SEM & p-Value \\
\hline Growth performance traits & 12.10 & 13.40 & 12.40 & 3.290 & 0.840 \\
Initial weight (kg) & 78.37 & 84.60 & 82.33 & 7.732 & 0.487 \\
Final weight (kg) & 66.24 & 71.22 & 69.91 & 6.772 & 0.527 \\
Total gain (kg) & 0.29 & 0.34 & 0.33 & 0.027 & 0.295 \\
ADG (kg/day) & 1.40 & 1.43 & 1.50 & 0.069 & 0.440 \\
ADFI intake (kg/day) & 4.44 & 4.20 & 4.38 & 0.316 & 0.529 \\
FCR & 18.20 & 18.75 & 18.00 & 1.110 & 0.603 \\
Back fat thickness (cm) & 157.20 & 153.84 & 154.42 & 4.812 & 0.526 \\
Age at puberty (day) & 44.23 & 41.17 & 43.80 & 6.063 & 0.717 \\
\hline Weight at puberty (kg) & & & & \\
\hline
\end{tabular}

Pearson's correlation coefficients between growth performances of Kolbroek boars are summarized (Table 3). There was a high positive correlation between ADFI and ADG ( $r=0.78)$. Moreover, a positive correlation existed between ADG and BFT $(r=0.12)$ accompanied by a high negative correlation between FCR and ADG $(\mathrm{r}=-0.94)$. Furthermore, negative correlations existed between feed intake and FCR $(\mathrm{r}=-0.57)$, feed intake and BFT $(r=-0.08)$ and FCR and BFT $(r=-0.02)$, SEM - Standard Error of the Mean.

Table 3. Pearson correlation coefficients in growth performances of Kolbroek boars.

\begin{tabular}{ccccc}
\hline Item & ADG & ADFI & FCR & BFT \\
\hline ADG & 1.00 & $*$ & $*$ & $*$ \\
ADFI & 0.78 & 1.00 & $*$ & $*$ \\
FCR & -0.94 & -0.57 & 1.00 & $*$ \\
BFT & 0.12 & -0.08 & -0.02 & 1.00 \\
\hline
\end{tabular}

ADG- average daily gain; ADFI- average daily feed intake; FCR-feed conversion ratio. 
Table 4. The effects of dietary protein levels on carcass traits and composition in Kolbroek pigs.

\begin{tabular}{|c|c|c|c|c|c|}
\hline \multirow[b]{2}{*}{ Item } & \multicolumn{5}{|c|}{ Levels of crude protein $\%$} \\
\hline & 10 & 13 & 16 & SEM & p-Value \\
\hline \multicolumn{6}{|c|}{ Carcass characteristics } \\
\hline P2 live (mm) & 19.49 & 19.50 & 19.54 & 0.707 & 1.000 \\
\hline Carcass length (cm) & $79.50^{\mathrm{b}}$ & $89.00^{\mathrm{a}}$ & $91.50^{\mathrm{a}}$ & 7.937 & 0.398 \\
\hline Warm carcass $(\mathrm{kg})$ & $69.75^{\mathrm{b}}$ & $76.30^{\mathrm{a}}$ & $75.27^{\mathrm{a}}$ & 10.010 & 0.796 \\
\hline Cold carcass (kg) & $67.51^{\mathrm{b}}$ & $74.70^{\mathrm{a}}$ & $73.75^{\mathrm{a}}$ & 9.872 & 0.753 \\
\hline Lean meat (\%) & $54.52^{\mathrm{a}}$ & $52.05^{\mathrm{a}}$ & $56.01^{\mathrm{a}}$ & 2.738 & 0.441 \\
\hline Dressing (\%) & $83.90^{\mathrm{a}}$ & $77.00^{\mathrm{a}}$ & $79.15^{\mathrm{a}}$ & 3.617 & 0.294 \\
\hline Water holding & $0.40^{\mathrm{a}}$ & $0.44^{\mathrm{a}}$ & $0.37^{\mathrm{a}}$ & 0.058 & 0.473 \\
\hline Fat depth (mm) & 52.53 & $50.28^{\mathrm{a}}$ & $51.90^{\mathrm{a}}$ & 5.053 & 0.948 \\
\hline Marbling mass & $1.54^{\mathrm{a}}$ & $2.00^{\mathrm{a}}$ & $2.51^{\mathrm{a}}$ & 1.000 & 0.650 \\
\hline Drip loss (\%) & $0.01^{\mathrm{a}}$ & $0.04^{\mathrm{a}}$ & $0.12^{\mathrm{a}}$ & 10.010 & 0.442 \\
\hline Eye Muscle Area & $30.05^{\mathrm{a}}$ & $38.00^{\mathrm{a}}$ & $37.50^{\mathrm{a}}$ & 6.251 & 0.190 \\
\hline Colour L* & $34.24^{\mathrm{a}}$ & $36.81^{\mathrm{a}}$ & $37.76^{\mathrm{a}}$ & 2.556 & 0.467 \\
\hline$a^{*}$ & $7.07^{\mathrm{a}}$ & $4.90^{\mathrm{a}}$ & $6.00^{\mathrm{a}}$ & 1.001 & 0.260 \\
\hline$b^{*}$ & $3.32^{\mathrm{a}}$ & $3.35^{\mathrm{a}}$ & $4.60^{\mathrm{a}}$ & 1.867 & 0.732 \\
\hline Loin area $\left(\mathrm{cm}^{2}\right)$ & $53.38^{\mathrm{b}}$ & $70.40^{\mathrm{a}}$ & $64.64^{\mathrm{ab}}$ & 4.905 & 0.084 \\
\hline
\end{tabular}

${ }^{\mathrm{a}-\mathrm{b}}$ Values with different superscript differs significantly $(\mathrm{P}<0.05) \mathrm{L}^{*}$ (lightness), $\mathrm{a}^{*}$ (redness), and $\mathrm{b}^{*}$ (yellowness), p-Value and SEM- standard error of the mean.

Table 5. The effects of dietary protein levels on the visceral organ characteristics of Kolbroek boars.

\begin{tabular}{cccccc}
\hline \multicolumn{5}{c}{ Levels of crude protein \% } \\
\hline Item & 10 & 13 & 16 & SEM & p-Value \\
\hline Heart & 0.21 & 0.20 & 0.23 & 0.001 & 0.503 \\
Pancreas & 0.10 & 0.10 & 0.11 & 0.002 & 0.392 \\
Lungs & 0.23 & 0.91 & 0.83 & 0.205 & 0.190 \\
Liver & 0.82 & 1.00 & 0.90 & 0.037 & 0.207 \\
Small intestine & 1.20 & 1.80 & 1.91 & 0.167 & 0.269 \\
Large intestine & 2.73 & 3.37 & 3.35 & 0.923 & 0.341 \\
Stomach & 2.43 & 2.57 & 2.79 & 0.053 & 0.248 \\
\hline
\end{tabular}

\section{Discussions}

Improvement of carcass quality is important for the economy and consumer satisfaction. Kolbroek pigs are a good source of protein and are popular with our local farmers because of its desirable traits. In this study, we have shown that by 
improving the carcass quality and growth performance through dietary crude protein supplementation, we can reduce BFT while improving carcass body weight and length. In addition, the age of puberty decreased accompanied by loss of weight at that age. According to Heyer and Lebret (2007), final body weight has no influence on carcass traits of Large White 70 and Large White 110 and did not modify the effects of feeding strategy on carcass traits [21]. However, Kerr et al. (1995) reported increases in carcass weight, BFT, lean meat thickness and lean percentage in $\mathrm{Du} \times \mathrm{LW}$ and $\mathrm{CH} \times \mathrm{LW}$ pigs when dietary protein levels were $17.3 \%$ high and $15.4 \%$ low [22]. In Yorkshire male pigs, increases in carcass traits with the increasing dietary protein supplementation were reported [23]. In contrast, Pharm et al. (2010) noted that carcass traits were significantly affected by dietary crude protein supplementation for BFT, longissimuss muscle length, dressing percentage, lean percentage and fat percentage, with the exception of carcass length [24]. Moreover, the ADG increased as was the ADFI. In this study, these parameters had high correlation as the protein supplementation was increased. Additionally, the FCR showed opposing relationships with ADFI and ADG. It has been reported that the optimal dietary crude protein content for maximum ADG was lowest for the Mong Cai boars (14.5\%) and medium for the Large White $\times$ Mong Cai boars (15.9\%) and highest for the Landrace $\times$ Mong Cai $\times$ Large White boars (16.4\%) [24]. Carpenter et al. (2004) and Nyachoti et al. (2000) reported a significant reduction in ADG and ADFI for diets containing a CP level of $19 \%$ or less while Madrid et al. (2013) reported that there were no significant effects of dietary treatment on performance traits measured in growing and the finishing period $(\mathrm{LW} \times \mathrm{LR})$ pigs [25] [26] [27]. Similarly, it has been reported that a strong correlation exists between ADFI and ADG [28] [29]. In addition, it has been indicated that dietary protein supplementation increased the ADG and lean percentage and subsequently decreased the FCR and BFT [30]. Others have shown that increasing the dietary protein level accelerated the increase in ADG in Kadon pigs [31]. In addition, feed intake increased as dietary protein levels were increased in growing to finishing pigs [32].

In this study, WHC appears to decrease as the protein supplementation was increased. In addition, Hong et al. (2016) reported that WHC was decreased by the effect of phase feeding through dietary protein levels in growing pig ([Yorkshire $\times$ Landrace] $\times$ Duroc) crosses and WHC was decreased and cooking loss was also increased as dietary protein level reduced [33]. Cromwell et al. (1993) reported that increasing the dietary protein or lysine level resulted in improved rates of gain and increased carcass of (Landrace $\times$ Mong Cai) $\times$ Large White [34]. Interestingly, pigs fed low protein diets have been shown to have fatter carcasses compared with those fed high protein diets [22] [35]. However, in our case, crude protein supplementation decreased BFT.

We also found that lungs, liver, small and large intestine and stomach were all increased as the protein supplementation was increased. Despite others reporting that the decreasing dietary $\mathrm{CP}$ level decreased the relative organ weights of 
liver, heart and pancreas, we have made opposing observation [22] [36] [37]. Heo et al. (2010) reported that reduction in pancreas weight of pigs fed low-CP diets suggested a reduced amount of pancreatic protease, which could be required to digest the smaller quantity of consumed protein [37]. It has been reported that the weights of small and large intestine and stomach were higher in pigs fed the high protein than those fed the low protein diets in agreement with our study [38] [39] [40]. Shortcomings and limitations of this study include the fact that the differences obtained due to various protein diets are very small and often insignificant. However, the overall benefits per carcass could account for greater profits for farmers.

\section{Conclusion}

We have shown in this study that we can improve Kolbroek carcass quality by using CP dietary supplementation. These improvements were shown by increases in body weight, length, visceral organs and decreases in BFT and the days of attainment of puberty. This means that inclusion of protein in the diet of Kolbroek will have returns for the farmer, but it also means that the farmers have to spend more in the diet to have these returns. Therefore, this model might not be viable for poor farmers and thus prompt for more research on improving the diets for Kolbroek boars.

\section{Acknowledgements}

This work would not have been possible without the financial support of Agricultural Research Council-Number: P0100935-02-36. In addition, I would like to extend thanks to all of those with whom I had the pleasure to work with throughout the duration of this project.

\section{Conflicts of Interest}

The authors declare no conflicts of interest regarding the publication of this paper.

\section{References}

[1] Swart, H., Kotze, A., Olivier, P.A.S. and Grobler, J.P. (2010) Microsatellite-Based Characterization of Southern African Domestic Pigs (Sus scrofadomestica). South African Journal of Animal Science, 40, 121-132. https://www.ajol.info/index.php/sajas/article/viewFile/57280/45663 https://doi.org/10.4314/sajas.v40i2.57280

[2] Anugwa, F.O.I. and Okwori, A.I. (2008) Performance of Growing Pigs of Different Genetic Groups Fed Varying Dietary Protein Levels. African Journal Biotechnology, 15, 2665-2670. http://www.academicjournals.org/AJB

[3] Netshirovha, T.R. (2015) Protein Accretion and Its Effects on Growth Rate and Testicular Traits of Kolbroek Boars. MTech. Dissertation, Central University of Technology, Welkom.

[4] Kim, G.-W. and Kim, H.-Y. (2017) Effects of Carcass Weight and Back-Fat Thick- 
ness on Carcass Properties of Korean Native Pigs. Korean Journal for Food Science of Animal Resources, 37, 385-391. https://doi.org/10.5851/kosfa.2017.37.3.385

[5] Ramsay, K.A., Reed, D.S., Bothma, A.J. and Lepen, J.M. (1994) Profitable and Environmentally Effective Farming with Early Domesticated Livestock in Southern Africa. Department of Agriculture, Arcadia.

[6] Chinnamani, K., Sivakumar, T., Gnanaraj, T.P. and Murugan, M. (2008) Carcass Characteristics of Crossbred Large White Orkshire Pigs under Different Feeding Regimens. Journal of Vetenary and Animal Science, 6, 211-214. http://krishikosh.egranth.ac.in/handle/1/88373

[7] Egerszegi, I., Ratky, J., Solti, L. and Brussow, K.P. (2003) Mangalica-An Indigenous Swine Breed from Hungary (Review). Archives Animal Breeding, 46, 245-256. https://doi.org/10.5194/aab-46-245-2003

[8] Newcom, D.W., Stalder, K.J., Baas, T.J. and Goodwin, R.N. (2004) Breed Differences and Genetic Parameters of Myoglobin Concentration in Porcine Longissimus Muscle. Journal of Animal Science, 82, 2264-2268. https://www.ncbi.nlm.nih.gov/pubmed/15318723 https://doi.org/10.2527/2004.8282264x

[9] Wang, J.J., Chen, L.X. and Li, P. (2008) Gene Expression Is Altered in Piglet Intestine by Weaning and Dietary Glutamine Supplementation. Journal Nutrition, 138, 1025-1032. https://doi.org/10.1093/jn/138.6.1025

[10] Chimonyo, M., Bhebhe, E., Dzama, K., Halimani, T.E. and Kanengoni, A. (2005) Improving Smallholder Pig Production for Food Security and Livelihood of the Poor in Southern Africa. Proceedings of the African Crop Science Conference, 7, 569-573.

[11] Whitney, M.H., Shurson, G.C., Johnston, L.J., Wulf, D.M. and Shanks, B.C. (2006) Growth Performance and Carcass Characteristics of Grower-Finisher Pigs Fed High Quality Corn Distillers Dried Grain with Solubles Originating from a Modern Midwestern Ethanol Plant. Journal of Animal Science, 84, 3356-3363.

https://doi.org/10.2527/jas.2006-099

[12] Louis, G.F., Lewis, A.J., Weldon, W.C., Ermer, P.M., Miller, P.S., Kittok, R.J. and Stroup, W.W. (1994) The Effect of Energy and Protein Intakes on Boar Libido, Semen Characteristics, and Plasma Hormone Concentrations. Journal Animal Science, 72, 2051-2060. https://www.ncbi.nlm.nih.gov https://doi.org/10.2527/1994.7282051x

[13] Lakhani, G.P. and Jogi, S. (2000) Studies on Back Fat Thickness of Indigenous Pigs and Their Large White Yorkshire Crosses. Indian Journal of Animal Research, 34, 80-81.

[14] Flowers, W.L. (2002) Increasing Fertilizing Rate of Boars: Influence of Number and Quality of Spermatozoa Inseminated. Journal of Animal Science, 80, 47-53.

[15] Umesiobi, D.O. (2010) Boar Effects and Their Relations to Fertility and Litter Size in Sows. South African Journal of Animal Science, 40, 471-475.

[16] Agricultural Research Council ARC (1980) The Nutrient Requirements of Ruminants Livestock. Commonwealth Agricultural Bureaux, London, 351 p.

[17] Kanengoni, A.T., Chimonyo, M., Erlwanger, K.H., Ndimba, B.K. and Dzam, K. (2014) Growth Performance, Blood Metabolic Responses, and Carcass Characteristics of Grower and Finisher South African Windsnyer-Type Indigenous and Large White $\times$ Landrace Crossbred Pigs Fed Diets Containing Ensiled Corncobs. Journal of Animal Science, 92, 5739-5748. https://doi.org/10.2527/jas.2014-8067 
[18] Hofmann, A.W. and White, W.M. (1982) Mantle Plumes from Ancient Oceanic Crust. Earth and Planetary Science Letters, 57, 421-436. https://doi.org/10.1016/0012-821X(82)90161-3

[19] Shapiro, S.S. (1965) An Analysis of Variance Test for Normality (Complete Samples). Biometrika, 52, 591-611. https://doi.org/10.1093/biomet/52.3-4.591

[20] Snedecor, G.W. and Cochran, W.G. (1980) Statistical Methods. Seventh Edition, Iowa State University Press, Ames.

[21] Heyer, A. and Lebret, B. (2007) Compensatory Growth Response in Pigs: Effects on Growth Performance, Composition of Weight Gain at Carcass and Muscle Levels, and Meat Quality. Journal Animal Science, 85, 769-778.

https://academic.oup.com/jas/article-abstract/85/3/769/4778246

https://doi.org/10.2527/jas.2006-164

[22] Kerr, B.J., Keith, F.K. and Easter, R.A. (1995) Effect on Performance and Carcass Characteristics of Nursery to Finisher Pigs Fed Reduced Crude Protein, Amino Acid-Supplemented Diets. Journal Animal Science, 73, 433-440.

https://www.ncbi.nlm.nih.gov/pubmed/7601776 https://doi.org/10.2527/1995.732433x

[23] Mederos, C.M., Valdivia, J.M.P., Piloto, J.L., Alemán, E. and Martínez, R.M. (2002) Protein Level and Amino Acid Supplementation in Pigs Fed Sugar Cane Molasses. Growth Performance and Carcass Traits. Livestock Research for Rural Development, 14, 6. https://www.lrrd.cipav.org.co

[24] Pham, K.T., Hoang, N.D., Duc, N.L., Hendriks, W.H., van der Peet-Schwering, C.M.C. and Verstegen, M.W.A. (2010) Effect of Genotype and Dietary Protein Level on Growth Performance and Carcass Characteristics of Fattening Pigs in Central Vietnam Asian-Aust. Journal Animal Science, 23, 1034-1042.

https://www.researchgate.net/publication/234012793

https://doi.org/10.5713/ajas.2010.90530

[25] Carpenter, D.A., O’Mara, F.P. and O'Dohertyt, J.V. (2004) The Effect of Dietary Crude Protein Concentration on Growth Performance, Carcass Composition and Nitrogen Excretion in Entire Grower-Finisher Pigs. Irish Journal of Agricultural and Food Research, 43, 227-236. https://about.jstor.org/terms

[26] Nyachoti, C.M., de Lange, C.F.M., McBride, B.W., Leeson, S. and Schulze, H. (2000) Dietary Influence on Organ Size and in Vitro Oxygen Consumption by Visceral Organs of Growing Pigs. Science, 40, 229-237.

https://doi.org/10.1016/S0301-6226(00)00157-3

[27] Madrid, J., Martínez, S., López, C., Orengo, J., López, M.J. and Hernández, F. (2013) Effects of Low Protein Diets on Growth Performance, Carcass Traits and Ammonia Emission of Barrows and Gilts. Animal Production Science, 53, 146-153.

https://www.researchgate.net/publication/262063487 https://doi.org/10.1071/AN12067

[28] Labroue, F., Guéblez, R. and Sellier, P. (1997) Genetic Parameters of Feeding Behaviour and Performance Traits in Group-Housed Large White and French Landrace Growing Pigs. Genetic Selection Evolution, 29, 451-468.

https://www.researchgate.net/publication/26631422 https://doi.org/10.1186/1297-9686-29-4-451

[29] Hyun, Y. and Ellis, M. (2002) Effect of Group Size and Feeder Type on Growth Performance and Feeding Patterns in Growing Pigs. Journal of Animal Science, 79, 803-810. https://www.ncbi.nlm.nih.gov/pubmed/11325183 https://doi.org/10.2527/2001.794803x 
[30] Zhou, P., Zhang, L., Li, J., Luo, Y., Zhang, B., Xing, S., Zhu, Y., Sun, H., Gao, F. and Zhou, G. (2015) Effects of Dietary Crude Protein Levels and Cysteamine Supplementation on Protein Synthetic and Degradative Signalling in Skeletal Muscle of Finishing Pigs. PLoS ONE, 10, e0139393.

https://doi.org/10.1371/journal.pone.0139393 https://journals.plos.org/plosone/article?id=10.1371/journal.pone.0139393

[31] Vasupen, K., Yuangklang, C., Wongsuttravas, S., Mitchaothai, J., Everts, H. and Beynen, A.C. (2014) Effect of Increasing Dietary Protein Level on Feed Intake, Growth Performance and Nitrogen Utilization in Kadon Pigs. Journal of Animal Science and Biotechnology, 95, 50-60. http://www.scielo.br/scielo.php?pid=S1516-35982019000100516

[32] Prandini, A., Sigolo, S., Morlacchini, M., Grilli, E. and Fiorentini, L. (2013) Microencapsulated Lysine and Low-Protein Diets: Effects on Performance, Carcass Characteristics and Nitrogen Excretion in Heavy Growing-Finishing Pigs. Journal Animal Science, 91, 4226-4234. https://doi.org/10.2527/jas.2013-6412

[33] Hong, J.S., Lee, G.I., Jin, X.H. and Kim, Y.Y. (2016) Effect of Dietary Energy Levels and Phase Feeding by Protein Levels on Growth Performance, Blood Profiles and Carcass Characteristics in Growing-Finishing Pigs. Journal of Animal Science and Technology, 58, 37. https://doi.org/10.1186/s40781-016-0119-Z

[34] Cromwell, G.L., Cline, J.D., Crenshaw, R.C., Evan, C.R., Hamilton, A.J., Lewis, D.C., Mahan, E.R., Miller, J.E., Pettigrew, L.F., Tribble, T.R. and Veum, T.L. (1993) The Dietary Protein and (or) Lysine Requirement of Barrows and Gilts. Journal of Animal Science, 71, 1510-1519. https://doi.org/10.2527/1993.7161510x

[35] Tuitoek, J.K., Young, L.G., de Lange, C.F. and Kerr, B.J. (1997) Body Composition and Protein and Fat Accretion in Various Body Components in Growing Gilts Fed Diets with Different Protein Levels But Estimated to Contain Similar Levels of Ideal Protein. Journal of Animal Science, 75, 1584-1590. https://doi.org/10.2527/1997.7561584x

[36] Deng, D., Huang, R.L., Li, T.J., Wu, G.Y., Xie, M.Y. and Tang, Z.R. (2007) Nitrogen Balance in Barrows Fed Low Protein Diets Supplemented with Essential Amino Acids. Livestock Science, 109, 225-247. http://www.elsevier.com/locate/livsci https://doi.org/10.1016/j.livsci.2007.01.122

[37] Heo, J.M., Levanon, N.L., Taylor, E.B., Jones, K.T., Dephoure, N., Ring, J., Xie, J., Brodsky, J.L., Madeo, F., Gygi, P.S., Ashrafi, K., Glickman, M.H. and Rutter, J. (2010) A Stress-Responsive System for Mitochondrial Protein Degradation. Molecular Cell, 70, 1582-1590.

[38] Morales, A.L., Buenabad, G., Castillo, N., Arce, B.A., Araiza, J.K., Htoo and Cervantes, M. (2015) Low-Protein Amino Acid-Supplemented Diets for Growing Pigs: Effect on Expression of Amino Acid Transporters, Serum Concentration, Performance, and Carcass Composition. Journal of Animal Science, 93, 2154-2164. https://doi.org/10.2527/jas.2014-8834

[39] Schaart, M.W., Schierbeek, H., van der Schoor, S.R.D., Stoll, B., Burrin, D.G., Reeds, P.J. and van Goudoever, J.B. (2005) Threonine Utilization Is High in the Intestine of Piglets. Journal Nutrition, 135, 765-770. https://academic.oup.com/jn/article/135/4/765/4663762 https://doi.org/10.1093/jn/135.4.765

[40] Anugwa, F.O.L., Varel, V.H., Dickson, J.S., Pond, W.G. and Krook, L. (1989) Effects of Dietary Fiber and Protein Concentration on Growth, Feed Efficiency, Visceral Organ Weights and Large Intestine Microbial Populations of Swine. American Institute of Nutrition, 23, 7-10. https://works.bepress.com/james 